\title{
Pengembangan strategi e-commerce dan CRM pada Lazada.com dalam menghadapi globalisasi
}

\section{The Development of e-commerce and CRM strategy on Lazada.com to face the globalization}

\author{
Indra Gamayanto*1 \\ ${ }^{1}$ Universitas Dian Nuswantoro,Semarang; Jl.Imam Bonjol No.207, Telp: (024)3517261,Fax: \\ (024)3569684 \\ ${ }^{1}$ Departemen Sistem Informasi, Fakultas Ilmu Komputer,UDINUS,Semarang \\ e-mail: *1indra.gamayanto@dsn.dinus.ac.id
}

\begin{abstract}
Abstrak
Berkembanganya teknologi informasi terutama di bidang e-commerce memberikan dampak yang besar terhadap gaya hidup masyarakat pada umumnya. Lazada merupakan salah satu business online terbesar di Indonesia dan merupakan sebuah entitas e-commerce yang memberikan dampak dan/atau pengaruh terhadap kehidupan masyarakat sehari-hari. Semua pola kehidupan masyarakat dapat berubah, mulai dari cara menggunakan barang-barang konsumtif sampai pada kebutuhan yang sangat penting lainnya. Lazada menjadi salah satu business online yang memiliki pengaruh besar, tidak hanya kepada gaya hidupnya, tetapi pada inovasi-inovasi yang dimilikinya. Metode McKinsey, merupakan metode yang sangat tepat untuk digunakan dalam menganalisis lazada, dan hubungan antara IT-IS dan business strategy harus dapat dilihat dengan saling menghubungkannya satu sama lain. Kedua metode ini akan memberikan sebuah inocasi e-commerce baru kepada lazada dalam menghadapi persaingan global ini. Lazada mampu bertahan dalam hal ini, karena melakukan inovasi penawaran yang menarik konsumen, ini di satu sisi, di sisi lainnya, lazada harus tetap mengembangkan inovasinya ke arah bagaimana konsumen dapat lebih jauh terlibat di dalamnya sehingga inovasi tersebut tidak berhenti sampai kepada penawaran produk, tetapi kepada sisi lain dari hal tersebut, seperti pola-pola segmentasi, pola kebutuhan konsumen yang utama, sehingga lazada akan dapat lebih jauh lagi dekat kepada konsumennya. Hal ini akan dapat memberikan dampak sangat besar.
\end{abstract}

Kata kunci-Lazada, IS/IT strategic planning, Mckinsey methods, e-commerce, e-business

\begin{abstract}
The development of information technology, especially in the field of e-commerce has a great impact on people's lifestyles in general. Lazada is one of the largest online businesses in Indonesia and is an e-commerce entity that impacts and / or influences people's everyday lives. All life patterns of society can change, ranging from how to use consumer goods to other very important needs. Lazada became one of the online business that has a great influence, not only on his lifestyle, but on the innovations he has. McKinsey's method is an excellent method to use in analyzing lazada, and the relationship between IT-IS and business strategy must be seen by interconnecting with each other. Both of these methods will provide a new e-commerce inauguration to lazada in the face of this global competition. Lazada is able to survive in this regard, because of the innovative offerings that attract many consumers, on the other hand, lazada must keep developing innovation in the direction of how consumers can be more involved in it so that innovation does not stop up to product offerings, but to the other side of the thing, such as the pattern of segmentation and the pattern of consumer needs
\end{abstract}

Keywords - Lazada, IS/IT strategic planning, Mckinsey methods, e-commerce, e-business 


\section{PENDAHULUAN}

Perkembangan e-commerce di dunia saat ini berkembang dengan sangat pesat, perkembangan ini merubah seluruh gaya hidup masyarakat di dunia dan perubahan yang terjadi sangat signifikan, mulai dari cara bertransaksi sampai kepada cara bagaimana berkomunikasi. Pertumbuhan yang pesat ini harus juga berdampingan dengan perkembangan sumber daya manusia. Perusahaan, satu sama lain, bersaing untuk dapat memuaskan konsumen, untuk dapat menjaga hubungan dengan konsumen dan untuk dapat memberikan layanan yang terbaik. Banyak perusahaan melakukan penawaran dan melakukan sebuah branding special untuk dapat memperkuat positioningnya di benak para pelanggan, memberikan layanan dengan diferensiasi yang unik dan penawaran yang sangat diinginkan oleh konsumen. CRM merupakan sebuah entitas penting yang harus dapat dibangun oleh setiap perusahaan, salah satu perusahaan yang dapat membangun CRM dengan baik, yaitu Lazada. Sebuah perusahaan yang bergerak di bidang business online yang mengembangkan jaringannya dengan memberikan layanan yang luar biasa kepada konsumennya, mulai dari penawaran special, promo produk, promo layanan dan penawaran lainnya yang membuat konsumen ingin berbelanja. Tingkat kenyamanan dan kehandalan dari teknologi informasi dan sistem informasi yang dimiliki oleh Lazada membuat perusahaan ini menjadi salah satu perusahaan yang terkuat di Indonesia, menjadikan dirinya salah satu raksasa e-commerce di tengah-tengah masyarakat milineum. Oleh sebab itu, Lazada terus melakukan inovasi untuk dapat mengembangkan layanan, jaringannya dan hubungannya dengan seluruh pelanggan di Indonesia dan juga seluruh dunia.

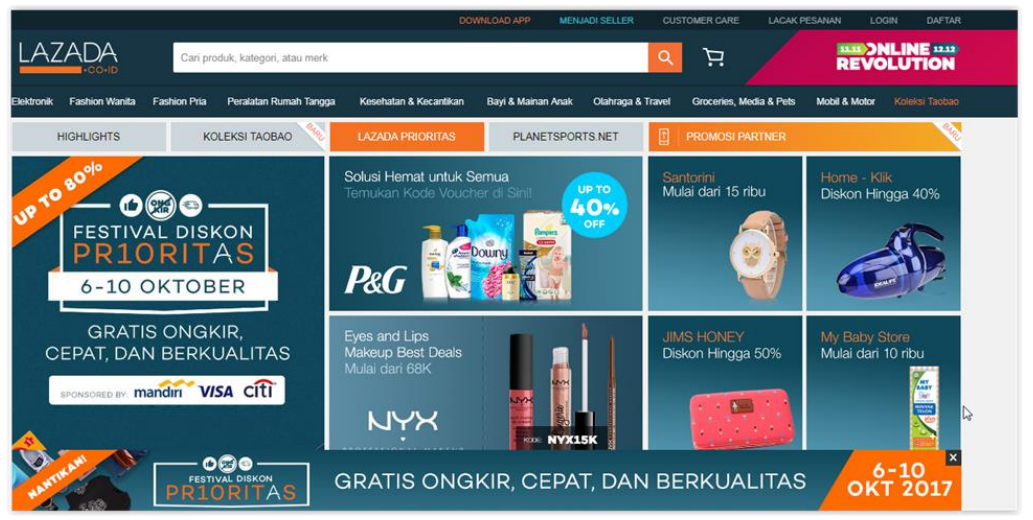

Gambar 1 Lazada.com

Gambar 1 dapat dilihat adalah merupakan website dari lazada. Lazada sudah mengembangan website layanannya sedemikian rupa sehingga konsumen dapat nyaman dalam menggunakannya. Beberapa feature telah ditambahkan dan diperbaharui, promosi tetap pada tampilan depan sebagai strategi CRM dari lazada kepada konsumennya, sehingga konsumen dapat mengetahui promo apa saja yang ditawarkan oleh lazada. Dalam jurnal ini, kita akan menganalisis lazada dengan menggunakan the 7S McKinsey, dimana metode ini akan menjelaskan kepada kita, kekuatan apa saja yang dimiliki oleh lazada dari sisi hard skills dan soft skills. Berikutnya kita akan menganalisis dengan sebuah framework "The relationship between business, IS and IT strategies", dengan menggunakan kedua metode ini, maka akan dihasilkan dan diketahui inovasi apa saja yang harus dilakukan oleh lazada dalam mempertahankan bisnisnya di masa depan, tentunya hal ini terus membutuhkan pengembangan strategi business online, yang tidak berhenti sampai pada inovasi yang direkomendasikan. 


\section{METODE PENELITIAN}

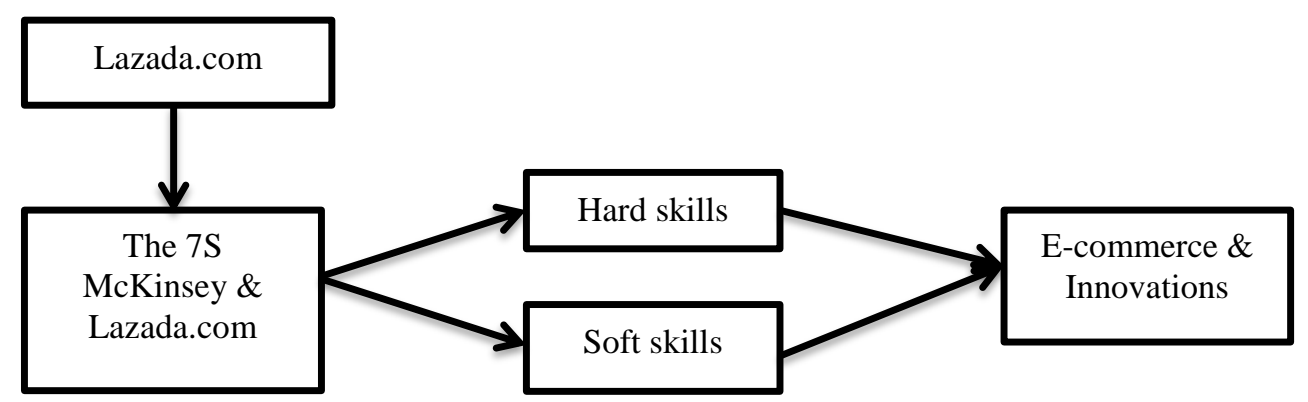

Gambar 2 Lazada-McKinsey-Innovations

Pada Gambar 2, kita dapat melihat sebuah proses. Proses ini merupakan proses dimana pertama-tama kita menganalisis website lazada.com, berikutnya dengan menggunakan metode 7S McKinsey, kita akan menganalisis lazada.com.

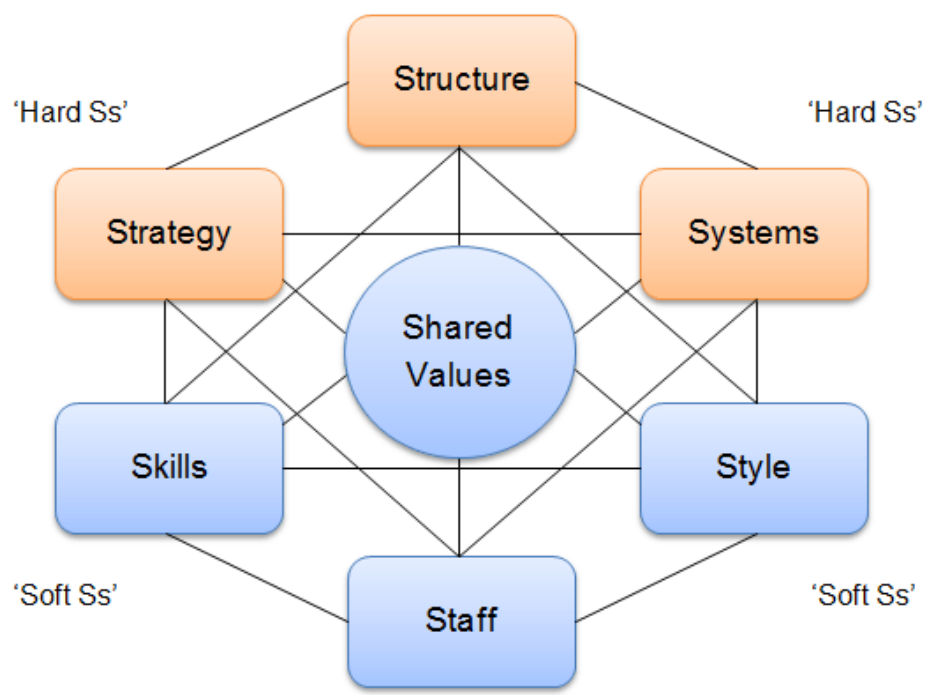

Gambar 3 7S McKinsey[7]

Gambar 3, dapat dijelaskan sebagai berikut: pada bagian hard skills- systems: sistem informasi dan teknologi yang dikembangkan organisasi harus mampu mendukung shared value yang ada. Sistem-sistem manajemen kinerja modern yang dikembangkan pada saat ini dapat diaplikasikan untuk mendukung shared vision yang ada (Apa sistem utama yang menjalankan organisasi? Perhatikan juga sistem-sistem finansial, sumber daya manusia, komunikasi dan tempat penyimpanan dokumen; dimana pengendalian sistem dilakukan dan bagaimana pemantauan dan evaluasi sistem?; apa peraturan-peraturan internal dan proses-proses yang digunakan tim agar menjaga tetap pada jalur yang benar?); structure: struktur organisasi merupakan cerminan dari shared vision organisasi dalam upaya mencapai sasaran dan tujuan strategic. Struktur yang sanggup mewujudkan shared vision dengan baik akan memberdayakan organisasi untuk mencapai sasaran dan tuuan strategic itu. Struktur organisasi dari sistem-sistem manajemen kinerja modern yang berorientasi proses pada umumnya berbentuk matriks (Bagaimana struktur organisasi dibangun?; apa hirarki manajemen yang ada?; bagaimana aktivitas koordinasi dari berbagai departemen?; bagaimana anggota-anggota tim mengorganisasikan dan menyelaraskan di antara mereka?; apakah pembuatan keputusan dan pengendalian bersifat terpusat atau desentralisasi?; dimana lini komunikasi?; apakah eksplisit 
atau implisit?); strategy: merupakan rencana-rencana strategic untuk mengembangkan organisasi agar membentuk keuungulan kompetitif di pasar global yang hiperkompetitif. Berbagai sasaran dan tujuan strategic yang telah dirumuskan harus disebarluaskan ke seluruh anggota organisasi melalui perencanaan strategic yang mantap (apa yang merupakan strategi organisasi?; bagaimana mencapai tujuan-tujuan strategic?; bagaimana berkaitan dengan tekanan kompetisi?; bagaimana menanggapi perubahan permintaan pelanggan?; bagaimana strategi itu disesuaikan terhadap isu-isu lingkungan?). Pada bagian soft skills, Style: merupakan gaya manajemen dan kepemimpinan organisasi yang diadopsi untuk memperlancar pencapaian shared vision beserta sasaran dan tujuan-tujuan strategic perusahaan yang telah dirumuskan (bagaimana gaya manajemen dan kepemimpinan organisasi?; bagaimana efektivitas kepemimpinan itu?; apakah anggota tim dapat bekerja sama atau saling bersaing?; Staff: merupakan anggota-anggota organisasi yang harus mewujudkan shared vision dari organisasi agar mampu mencapai sasaran dan tujuan-tujuan strategic yang telah dirumuskan oleh manajemen (apa posisi atau spesialisasi yang diwakili oleh tim?; apa posisi-posisi yang perlu diisi?; apakah ada kesenjangan terhadap kompetensi yang dibutuhkan?; Skills: merupakan ketrampilan dan kompetensi actual dari semua anggota organisasi yang harus terus menerus dikembangkan agar mampu mewujudkan shared vision beserta sasaran dan tujuan-tujuan strategic yang telah dirumuskan (apa ketrampilan terbaik yang dimiliki oleh perusahaan atau tim?; apakah terdapat kesenjangan ketrampilan?; apakah tim mengetahui pekerjaan dengan baik?; apakah anggota-anggota tim memiliki kemampuan untuk menyelesaikan pekerjaan dengan baik?; bagaimana ketrampilan dimonitor dan dinilai?)

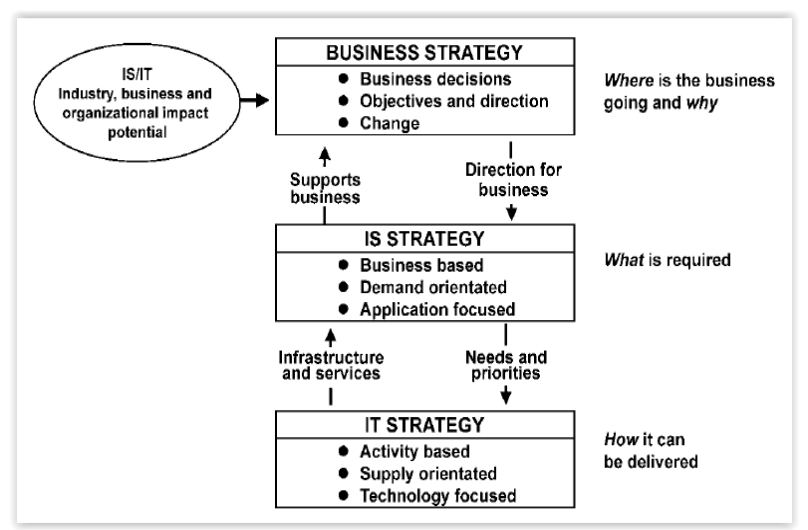

Gambar 4 Business-IS-IT Strategy[1]

Pada Gambar 4, dapat kita lihat terdapat 3 bagian penting yang tidak dapat dipisahkan satu sama lain, pada bagian IT strategy, terdapat 3 fokus yang menjadi pusatnya- teknologi yang digunakan dan bagaimana teknologi dapat membantu. Ini merupakan sisi hard skills di McKinsey. Sedangkan pada bagian IS strategy, terdapat juga 3 fokus utama yang tidak kalah pentingnya, yang ada pada sisi soft skills di McKinsey. Pada bagian akhir akan dihasilkan sebuah tingka inovasi yang berguna untuk lazada di masa depan. Jika kedua metode ini digabungkan, maka sisi teknologi dan bisnis merupakan kombinasi yang akan dapat memberikan pengaruh pada bertahan atau tidaknya lazada di masa depan, dengan menerapkan kedua metode ini akan dapat dihasilkan inovasi apa yang dibutuhkan oleh lazada dalam menghadapi persaingan. Perlu diperhatikan bahwa dalam Mckinsey memiliki shared vision yang menjadi pusat dari hard skills dan soft skills tersebut, shared vision adalah merupakan visi bersama yang melandasi berdirinya suatu organisasi. Visi perusahaan merupakan suatu pentunjuk bagi semua anggota organisasi untuk bertumbuh dan berkembang. Ketika mengembangkan visi organisasi, perlu memperhatikan beberapa kriteri berikut ini: (1) singkat dan mudah diingat; (2) diciptakan melalui consensus; (3) memiliki pengaruh dan menantang 
bagi orang-orang untuk berhasrat mencapai visi itu; (4) deskripsi dari keadaan ideal yang diinginkan; (5) memberikan arah dan focus bagi organisasi dan manajemen; (5) menarik bagi karyawan, pelanggan dan stakeholders; (6) deskripsi dari tingkat pelayanan, kualitas produk dan biaya yang diinginkan di masa mendatang; (7) bersifat tetap sepanjang waktu, selalu up-to-date.

\section{HASIL DAN PEMBAHASAN}

Lazada Group adalah perusahaan e-commerce Jerman milik swasta yang didirikan oleh Rocket Internet pada tahun 2011. Pada tahun 2014, Lazada Group mengoperasikan situs di Indonesia, Malaysia, Filipina, Singapura, Thailand, dan Vietnam dan telah mengumpulkan sekitar US \$ 647 juta selama beberapa putaran investasi. dari para investor seperti Tesco, Temasek Holdings, Summit Partners, JPMorgan Chase, Investment AB Kinnevik dan Rocket Internet. Situsnya diluncurkan pada bulan Maret 2012, dengan model bisnis menjual inventaris ke pelanggan dari gudangnya sendiri. Pada tahun 2013, ia menambahkan model pasar yang memungkinkan pengecer pihak ketiga menjual produk mereka melalui situs Lazada; pasar menyumbang 65\% dari penjualan pada akhir 2014. Pada April 2016, Alibaba Group membeli saham pengendali di Lazada untuk mendukung rencana ekspansi Alibaba di Asia Tenggara. Lazada Group didirikan pada tahun 2012 oleh Rocket Internet di Singapura dengan maksud untuk membangun model bisnis Amazon.com di Asia Tenggara untuk memanfaatkan pasar konsumen online yang baru lahir dan keberadaan Amazon yang lemah di sana; Rocket adalah inkubator Jerman yang membangun perusahaan yang menyalin model bisnis perusahaan teknologi AS yang sukses di pasar negara berkembang. Situs e-commerce Lazada diluncurkan pada tahun 2012 di Indonesia, Malaysia, Filipina, Thailand dan Vietnam. Ini mengumpulkan empat putaran pendanaan pada tahun 2012 dan awal 2013: JP Morgan menginvestasikan jumlah yang tidak diketahui pada bulan September, peritel Swedia Kinnevik menginvestasikan \$ 40 juta pada bulan November, perusahaan ekuitas swasta Jerman Summit Partners menginvestasikan \$ 26 juta pada bulan Desember, dan Tengelmann menginvestasikan sekitar \$ 20 juta pada bulan Januari 2013. Ini juga menambahkan layanan pengiriman 2 hari yang dijamin, menangani salah satu keluhan paling umum tentang layanan Lazada, dan salah satu tantangan terbesarnya, yang telah diusahakannya dengan membuat "investasi besar-besaran dan tak terhitung" di gudang dan pengiriman jasa. Pada bulan Juni 2013, Lazada mengumumkan telah mengumpulkan tambahan \$100 juta, dan meluncurkan aplikasi mobile untuk perangkat Android dan iOS. Pada bulan Desember 2013, perusahaan tersebut mengumpulkan tambahan $\$$ 250 juta dari Tesco PLC, Access Industries, dan investor lainnya yang ada. Pada bulan Mei 2014, Lazada diluncurkan di Singapura, negara keenamnya. Pada bulan November 2014, Temasek Holdings di Singapura memimpin putaran pendanaan sebesar \$ 250 juta, sehingga total Lazada meningkat menjadi sekitar \$ 647 juta. Juga pada bulan itu, Lazada mengumumkan bahwa platform pasarnya menyumbang lebih dari $65 \%$ dari keseluruhan penjualannya, dan bahwa jumlah penjual pihak ketiga di platform telah meningkat dari $\sim 500$ di bulan November 2013, menjadi mendekati 10.000 pada bulan Desember 2014. Jumlah karyawan di seluruh wilayah mencapai sekitar 4.000. Untuk tahun 2014, kerugian operasional Lazada adalah \$152,5 juta untuk pendapatan bersih sebesar \$ 154,3 juta. Namun, persentase kerugiannya terhadap Volume Merchandise Kotor - nilai semua produk yang terjual melalui situs - lebih kecil pada tahun 2014 daripada 2013 karena pertumbuhan GMV dari \$ 95 juta di tahun 2013 menjadi \$ 384 juta pada tahun 2014, didorong oleh penjualan pasar Pada tahun 2015, tantangan Lazada untuk pertumbuhan adalah pilihan untuk belanja batu bata dan mortir di antara pelanggan, dengan hanya sekitar $1 \%$ orang yang membeli secara online dibandingkan dengan $10 \%$ pembeli AS; kurangnya kartu kredit dan persyaratan bersamaan untuk mengatur arus kas pada sistem pengiriman, pengiriman yang andal terutama di daerah pedesaan, dan ancaman persaingan dari Amazon dan Alibaba. Pada bulan Maret 2016, Lazada mengklaim mencatat total \$ 1,36 miliar dalam bentuk tahunan di enam pasarnya di Asia, menjadikannya sebagai pemain e-commerce 
terbesar. Pada bulan April 2016, Alibaba Group mengumumkan bahwa mereka bermaksud mengakuisisi saham pengendali di Lazada dengan membayar \$ 500 juta untuk saham baru dan membeli saham senilai \$ 500 juta dari investor lama. Perusahaan supermarket Inggris Tesco mengkonfirmasi penjualan 8,6\% kepemilikannya di Lazada kepada Alibaba seharga \$ 129 juta. Alasan mengapa Alibaba tertarik adalah: Pasar Asia Tenggara telah menumbuhkan populasi pendapatan kelas menengah yang memperkirakan 190 juta orang di wilayah ini memiliki pendapatan sekali pakai sebesar \$16 - \$100 per hari untuk tumbuh menjadi 400 juta orang pada tahun 2020, Lazada juga telah menemukan betapa sulitnya di Asia Tenggara, bagi Alibaba, ini membantu menghemat miliaran dengan berinvestasi dari Lazada alih-alih membangun kembali e-commerce untuk pasar ini dengan logistik dan infrastruktur untuk mereplikasi pasar China, dan terakhir penjual China dari Alibaba Bisa juga akses ke penjual baru dan pembeli dari Lazada, ini bermanfaat bagi kedua perusahaan[2]. Ini merupakan sejarah singkat dari lazada. Berikutnya, kita akan menganalisis lazada dengan menggunakan 7S McKinsey, untuk dapat mengetahui sampai sejauh mana lazada sudah sampai dimana kemajuan yang telah mengalami beberapa perkembangan dalam menghadapi globalisasi saat ini.

\section{The 7S McKinsey \& Lazada.com}

Shared vision lazada- melihat website dari lazada, kita dapat melihat bahwa lazada memiliki sebuah statement sederhana yang kita semua dapat mengerti: "Lazada.co.id merupakan bagian dari Lazada Group yang menjadi tujuan belanja online nomor satu di Asia Tenggara. Lazada Group beroperasi di Indonesia, Malaysia, Filipina, Singapura, Thailand dan Vietnam. Menjadi pionir di bidang e-commerce, Lazada menghadirkan layanan berbelanja yang mudah bagi konsumen dan akses langsung pada database konsumen terbesar di Asia Tenggara". Selanjutnya, misi yang dimiliki oleh lazada, mengutip dari lazada Malaysia: Lazada Malaysia siap menjadi mal online terbesar yang merupakan bagian dari rantai cyber global yang sudah mapan di Eropa. Kami memiliki situs serupa di China, India, Singapura dan Filipina dengan rencana untuk mengembangkan jaringannya. Lazada Malaysia akan mengubah wajah belanja dengan menawarkan platform e-commerce yang user-friendly, nyaman dan terpercaya dan terakhir tujuan dari lazada adalah: Dengan ratusan ribu pilihan produk tersedia dari berbagai kategori, kesehatan dan kecantikan, peralatan rumah tangga, handphone dan tablet, elektronik, peralatan rumah tangga, Lazada menjadi tujuan utama untuk memenuhi kebutuhan berbelanja Anda. Selain dari berbagai pilihan produk dari brand internasional dan lokal, Anda juga dapat menemukan berbagai produk yang hadir secara eksklusif melalui Lazada.

Pada sisi hard skills- Systems; strategy; structure

A. Systems: lazada merupakan e-commerce dengan kehandalan yang sangat baik, dimana memiliki layanan pelanggan yang canggih. Hal tersebut meliputi: (1) kapan produk pesanan saya diterima?; (2) bagaimana caranya melakukan pengecekan pesanan saya?; (3) bagaimana membatalkan pesanan saya?; (4) bagaimana cara saya melakukan pengembalian barang?; (5) mengapa barang saya dikirim secara terpisah?; (6) metode pembayaran apa yang berbeda?; (7) bagaimana saya mengetahui, apakah pembayaran saya berhasil atau gagal?; (7) apa itu biaya kirim?; (8) dimana saya mendapatkan informasi lengkap tentang produk?; (8) apa itu produk yang dikirimkan dari luar negeri?

B. Strategy: lazada melakukan affiliate program untuk memperluas jaringannya. Lazada mendefinisikan affiliate dalam beberapa hal penting yang harus dipahami oleh konsumen, sebagai berikut: (1) Affiliate marketing adalah sebuah program di mana Anda memasangkan iklan sebuah situs untuk dipasang di situs Anda sendiri, lalu mendapatkan komisi dari setiap pembelian yang terjadi. Lazada membuka program Lazada affiliate program dengan komisi yang lebih tinggi, didukung dengan jaringan teknologi yang luas dan canggih sehingga Anda bisa menikmati cari uang di internet gratis dengan lebih menguntungkan. Bergabunglah dengan ribuan orang yang sudah merasakan sendiri keuntungan ikut Lazada affiliate program dan dapatkan penghasilan tambahan tanpa usaha yang lebih karena Lazada adalah marketplace 
terbesar di Asia Tenggara dengan jutaan konsumen yang terus bertambah. (2) Affiliate Lazada adalah program pemasaran afiliasi di mana Anda bisa memasukan iklan Lazada ke dalam halaman situs Anda. Apabila pengunjung situs tertarik dengan iklan dan melakukan klik pada iklan yang dipasang, kemudian melakukan pembelian produk apa saja maka Anda berhak mendapatkan jatah komisi tergantung dari nilai pembelian tersebut. Program afiliasi merupakan cara cari uang di internet karena Lazada memberikan jumlah komisi yang paling besar dalam industri affiliate marketing yang sudah matang menjadi marketplace nomor satu di Asia Tenggara. Keuntungan lain yang bisa Anda dapatkan dari afiliasi Lazada adalah laporan realtime, promo dan link untuk aplikasi mobile, cara daftar yang mudah dan cepat, dukungan 159rofessional dan teknologi marketing yang sudah mutakhir. Bagaimana cara menjadi affiliate di Lazada? Anda bisa mengunjungi halaman ini kemudian klik link Daftar Sekarang untuk mengisi aplikasi online yang sudah disediakan. Isi datanya dengan lengkap kemudian tim dari Lazada affiliate program akan melakukan review dari aplikasi Anda. Apabila aplikasi lolos dari ketentuan maka secara otomatis Anda akan terdaftar sebagai mitra afiliasi Lazada.(3) Afiliasi adalah tren mendapatkan uang dari internet yang saat ini sedang banyak digandrungi. Anda tidak butuh banyak modal untuk menjalani program ini namun keuntungan yang bisa didapat jumlahnya besar.

C. Structure: lazada memiliki penawaran kerja di lazada secara professional. Penawaran ini ditawarkan secara professional, sehingga orang-orang yang melihatnya akan memperoleh informasi yang sangat jelas.

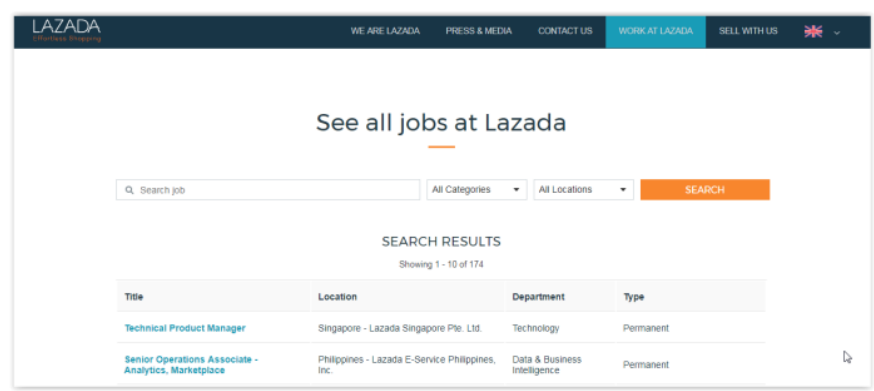

Gambar 5 Example of Jobs - lazada

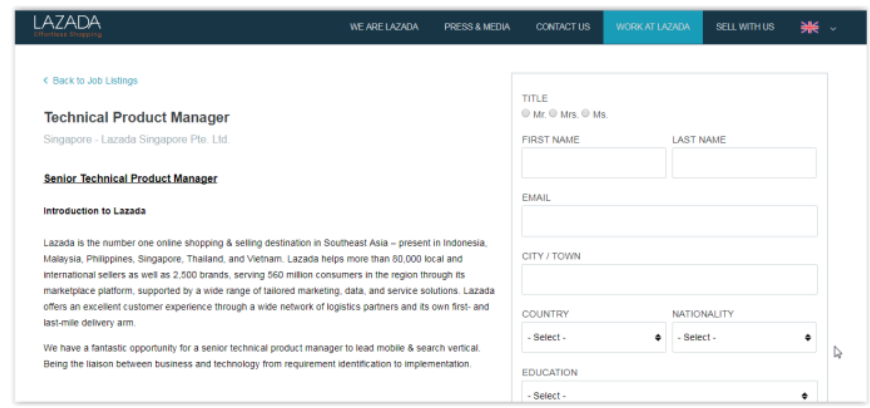

Gambar 6 Jobs description - lazada

Pada sisi soft skills: staff-style-skills

A. Style. Lazada memberikan hal terbaik pada staff yang bekerja dan menjelaskan hal-hal yang terbaik di dalamnya: Sebagai perusahaan muda dan dinamis, Lazada adalahtempat bagi para konsumen untuk dapat mengembangkan bisnisnya dan bagi yang ingin bekerja di lazada, ini merupakan tempat yang sangat menarik. Lazada tidak hanya mempresentasikan nilai-nilai keuntungan pribadi tetap membimbing untuk dapat berfokus pada masa depan. Hal-hal terhbat yang lazada lakukan adalah (1) Pengusaha dan pemilik, lazada membimbing agar setiap orang 
yang menggunakan lazada dapat menjadi seorang pengusaha dan pemilik toko online;(2) n dan penjual, lazada dapat membuat pelanggan merasa sangat nyaman dan dapat berjualan secara kreatif; (3) standar dan inovasi, inovasi pelayanan yang dilakukan oleh lazada dapat sangat membantu konsumen dalam memasarkan produknya; (5) komunikasi dan integritas, lazada menjaga komunikasi yang sangat dan menjaga integritas

B. Skills. Lazada memiliki staff yang handal, dimana akan sangat membantu lazada untuk dapat terus berkembang. Sebagai contoh: Technical Product Manager

Tanggung jawab

- Memahami pasar e-commerce Asia Tenggara, persaingan dan kebutuhan pelanggan / pengguna secara mendalam.

- Mengidentifikasi peluang pasar, membangun kasus bisnis, dan menentukan visi dan strategi produk untuk Lazada User Products (khususnya mobile and search).

- Bekerja sama dengan para insinyur dan teknologi terdepan.

Kualifikasi minimum:

- Gelar S1 di bidang Ilmu Komputer atau bidang teknik terkait, atau pengalaman praktis setara.

- 5 tahun pengalaman dalam strategi pengelolaan, teknik dan teknologi strategi.

- Pengalaman bekerja dalam e-commerce / mobile / search.

Kualifikasi yang diinginkan:

- S2 atau MBA atau gelar teknis lanjutan.

- Keterampilan organisasi, analitis dan mempengaruhi yang bagus.

- Memahami bahasa Mandarin dengan baik adalah nilai plus

Contoh di atas merupakan, salah satu deskripsi pekerjaan di lazada yang memiliki kualitas tinggi, dan hal itu akan meningkatkan kemajuan organisasi di dalam persaingan di dalam ecommerce.

C. Staff. Seperti yang telah dikemukakan sebelumnya, staff yang dimiliki oleh lazada merupakan staff yang sangat professional. Sebagai contoh:

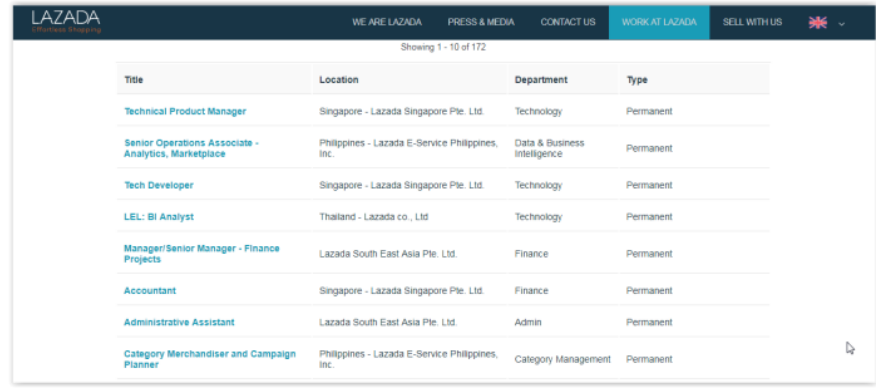

Gambar 7 Jobs list-lazada

Setelah melakukan analisis singkat dengan menggunakan 7S McKinsey, maka berikutnya hal ini menimbulkan pertanyaan penting: inovasi apa yang dapat dilakukan oleh lazada dalam menghadapi persaingan di era globalisasi?, hal-hal apa saja yang dapat memberikan lazada kemajuan yang lebih daripada perusahaan e-commerce lainnya?

\section{E-Commerce \& Innovasi}

Kita tahu pertumbuhan e-commerce sangat signifikan saat ini dan bertumbuh dengan sangat cepat sehingga hal tersebut akan dapat memberikan banyak perubahan di hampir semua sisi kehidupan manusia. Konsumen berubah, mulai dari gaya mereka dalam memilih produk sampai kepada cara pembelian mereka. Beberapa hal perubahan sikap ini dapat dilihat dalam beberapa konteks, antara lain: (1) kita lebih tidak menghargai produk dibandingkan sebelumnya; 
tetapi bagaimana kita terlibat dengan merek melalui pelayanan dan dukungan jauh lebih penting. (2) kita menghargai anak muda daripada usia lanjut dan kita ingin muda setiap saat, daripada melihat kepada yang lebih tua. (3) kita menghargai hidup daripada uang, memilih untuk berhubungan dengan modal seperti-pengetahuan, pertemanan, atau kebahagiaan daripada uang kortan. (4) kita berupaya untuk meningkatkan hal-hal yang kita nikmati atau anggap bernilai, dan untuk meminimalkan hal-hal yang kita tidak nikmati dan tidak penting bagi kita. Kita hidup di zaman konsumen telah menjadi sangat cerdas, dimana sebelum melakukan transaksi, konsumen mungkin sudah melakukan banyak riset produk atau membandingkan harga terlebih dahulu dengan sangat cermat. Kita bisa membeli apa saja darimana saja dan berharap untuk diantar keesokan harinya. Isu-isu etis juga menjadi sangat penting, bukan sebagai pilihan. Henley centre dalam risetnya mengatakan: (1) konsumen di Amerika serikat 60 persen percaya kepada Starbucks, sedangkan di inggris 36\% dan Prancis 12\%. (2) kita lebih percaya kepada bank kita daripada pengacara kita, meskipun fakta bahwa bank mengunci dengan rekening yang hasilnya memberikan keuntungan yang sangat kecil kepada kita. (3). Di Negara berkembang, orang-orang lebih percaya kepada merek global daripada merek lokal, tetapi orang-orang di Negara maju lebih percaya merek lokal daripada merek global.

Kita harus memahami bahwa konsumen adalah orang-orang biasa yang memiliki motivasi yang berbeda-beda di dalam dirinya, mereka tidak bisa disimpulkan dengan mudah sebagai rata-rata hasil dari sebuah analisis. Memahami bahwa 50\% lebih orang lebih suka buah apel daripada jeruk, tidak langsung berarti bahwa kita harus mengesampingkan hal lainnya, atau bahwa kita harus menciptakan kombinasi antara apel dan jeruk agar orang-orang tertarik untuk membelinya[3]. Ini kedengarannya akan sangat lucu, tetapi hal tersebut sering terjadi di dunia pemasaran. Banyak perusahaan bersedia menghabiskan uang jutaan dollar untuk anggaran analitis yang digunakan untuk mengerti sejumlah kecil konsumen secara mendalam, daripada berupaya untuk mencari arti dari hasil rata-rata sampel yang lebih besar. Tetapi, sebelum kita melompat ke dunia konsumen lebih jauh, kita harus focus kepada usaha kita untuk memuaskan konsumen yang lebih masuk akal dan paling bernilai bagi perusahaan. Sebagai contoh, segmentasi adalah persyaratan dasar untuk menghadapi perkembangan pasar e-commerce. Konsumen tidak semuanya sama, dalam hal motivasi dan nilai. Tidak ada perusahaan yang berupaya untuk menjadi apa saja untuk semua orang. Sedikit merek mendapatkan bagian pasar lebih dari 30-40\%, oleh sebab itu berupaya untuk 30-40\% yang anda pasti akan suka sebelum mencoba untuk melibatkan mereka. K. Ilieska mengatakan: Perusahaan harus mempertimbangkan faktor-faktor ini ketika itu menetapkan sejauh mana kebutuhan konsumen, yang penting untuk kegiatannya di pasar; kebutuhan bersifat dinamis dan mereka berubah karena faktor-faktor yang mempengaruhinya [4];lebih jauh lagi, F. C. Lunenburg mengatakan, bagian kunci dari organisasi, yaitu bagian dari organisasi yang memainkan peran utama dalam menentukan keberhasilan atau kegagalannya [5].

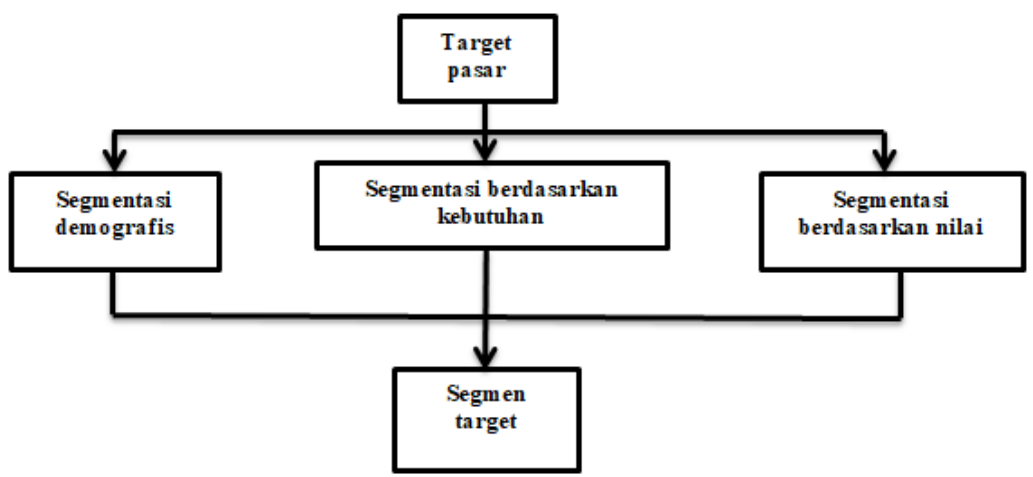

Gambar 8 segmentasi strategy[9] 
Gambar 8 menggambarkan sebuah pola strategi segmentasi, hal ini berguna untuk dapat melihat jauh lebih dalam. Hal ini akan dapat mengatakan kepada kita bahwa kita membutuhkan sesuatu yang baru dan berguna, dengan mempertimbangkan aspek-aspek yang tidak ada di pasar. Lebih jauh lagi, hal ini akan menempatkan pengetahuan sebagai konteks dan menjelaskan mengapa serta bagaimana sekaligus juga siapa dan apa. Langkah terpenting untuk mendapatkan hal terbaik adalah berhenti terlebih dahulu sejenak menggunakan riset seperti orang buta menggunakan lampion, artinya, berhenti mengumpulkan data lebih dari yang kita butuhkan, menolak keinginan untuk meriset setiap orang secara terus-menerus, dan menanyakan pertanyaan yang bisa ditanyakan. Terdapat juga godaan untuk melompat ke riset tanpa sasaran yang jelas, dan sering kali hasilnya terkadang mengatakan bahwa riset tersebut tidak memiliki tujuan tertentu, atau tidak dapat menjawab pertanyaan yang paling penting. Jawaban kemudian diperkirakan terlebih dahulu, menghukum atau membatasi respons, dengan pertanyaan atau pilihan. Terlalu banyak riset yang bertanya kepada konsumen untuk mengatakan apa yang mereka inginkan ketika mereka jarang dapat menggambarkan kebutuhan yang tidak terpenuhi, akan sangat menggoda untuk menggunakan teknik yang sama untuk semua riset, oleh karena itu metode yang paling mudah, atau yang paling dipilih oleh agen-agen riset terkemuka. Ini mengakibatkan bias, dan terkadang malah diaplikasikan oleh para manajer secara internal seperti kebijakan, praksangka, dan kemasalah sering membuat setiap hasil riset yang banyak memberikan manfaat menjadi hambar ketika disaring oleh para pembuat keputusan. Kita perlu memahami bahwa "bisnis harus mengadopsi pendekatan yang lebih mendalam untuk riset, interpretasi, dan pengambilan keputusan yang bisa menghasilkan sesuatu yang lebih inovatif. Riset harus dimulai dengan sebuah akhir, focus untuk belajar tentang konsumen terbaik, mencari anomaly dan hal-hal ekstrim daripada sesuatu yang sifatnya rata-rata. Gunakanlah teknik riset yang beragam, mulai dari mengui konsep dan mood hingga jaringan netral dan psikografis. Gali secara mendalam ke konsumen yang merupakan pusat data besar yang kebanyakan perusahaan besar tidak pernah tersentuh. Temukan bahasa baru untuk menggambarkan hal-hal yang terbaik mulai dari strategi, metafora, analogi yang dapat diterapkan di dalam e-commerce, terutama dalam menarik konsumen dalam membeli". Cobalah untuk lebih sering berjalan dengan sepatu konsumen, lihatlah dunia sebagaimana mereka melihatnya, cobalah produk atau jasa dari competitor, atau carilah solusi untuk masalah mereka dengan cara yang berbeda. Lakukan observasi bagaimana perilaku konsumen- apa yang sulit?; apa yang membuat mereka frustasi?; bagaimana mereka menggunakan dan menyimpan barangbarang?, semua hal-hal irasional yang kita semua lakukan, berbicaralah dengan konsumen kita. Pertimbangkanlah hal-hal sebagai berikut dalam segmentasi: (1) Kita telah memilih target pasar berdasarkan potensinya untuk menghasilkan pertumbuhan yang menguntungkan dan bisa bertahan. Tetapi tidak semua konsumen itu sama, pertimbangkanlah itu dengan cermat. (2) konsumen secara fisik berbeda, tetapi lebih berbeda lagi dalam hal kebutuhan dan motivasi mereka serta nilai jangka panjang potensial untuk bisnis kita. (3) segmentasi membuat kita bisa menargetkan konsumen yang paling berharga di pasar kita, dengan cara-cara yang lebih relevan, menyakinkan dan bisa diakses. (4) setiap segmen target harus diperlakukan secara berbeda, berdasarkan penawaran yang beragam, jalur, dan hubungan yang melibatkan mereka secara menguntungkan untuk jangka panjang[6]

Jadi pertanyaan pentingnya adalah: apakah yang harus dilakukan oleh lazada? Dan apa yang dapat lazada terapkan dalam hal ini?, hasil pada saat lazada mampu melakukan inovasi dalam segmentasi adalah sebagai berikut: 


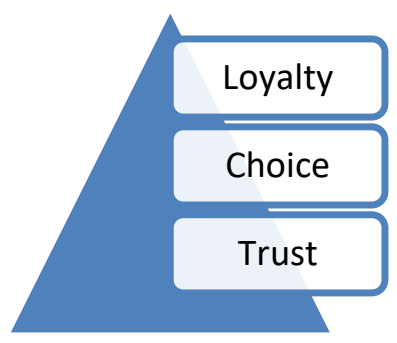

Gambar 9 Piramida kemajuan[8];[9]

Pada Gambar 9, kita melihat 3 tahap penting: trust-choice-loyalty. Pada titik trust, disini kita harus dapat membangun kepercayaan dan kesadaran kepada konsumen secara komprehensif. Dimana kebutuhan konsumen harus diperhatikan dan hal itu merupakan hal yang wajib dilakukan oleh lazada. Di sini kita berbicara tentang syarat absolut untuk merek apa saja yang mereka lihat sekaligus juga ekspektasi dasar yang diharapkan oleh konsumen.

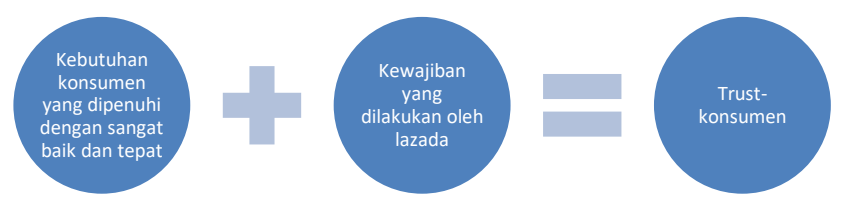

Gambar 10 Needs-Kewajiban-Trust[8];[9]

Pada titik choice, lazada harus dapat memberikan pilihan yang lebih inovatif dan membangun relevansi produk yang lebih luas, dimana keinginan konsumen harus dapat dipenuhi dan lazada harus dapat menghasilkan pelayanan yang berbeda dari situs business online lainnya. Faktor choice ini, secara praktis harus dapat membantu konsumen untuk melakukan hal yang lebih dari biasanya, hal ini mungkin bisa dilakukan dengan menawarkan beberapa merek tertentu dengan relevansi yang lebih terkait, layanan 24 jam yang sudah dilakukan oleh lazada sudah sangat baik, pengiriman yang lebih cepat dan aman perlu ditingkatkan lagi, dengan melihat kondisi di Indonesia dan kebudayaan yang dimiliki oleh setiap Negara.

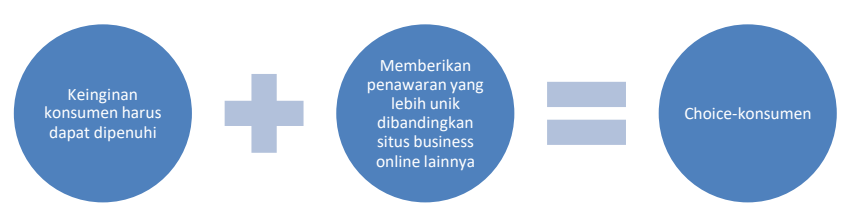

Gambar 11 Wants-unique-choice[8];[9]

Pada titik loyalty. Di sini perlu dibangun sebuah hubungan yang emosional dengan konsumen, dimana aspirasi konsumen harus sangat details diperhatikan, karena walaupun kelihatan kecil dan sepele, tetapi secara emosional akan dapat menghasilkan perbedaan yang besar di dalam peningkatan profit di lazada. Oleh sebab itu, lazada membutuhkan faktor pembeda dalam melakukan pendekatan dengan konsumen dengan memperhatikan hal-hal yang kecil. 


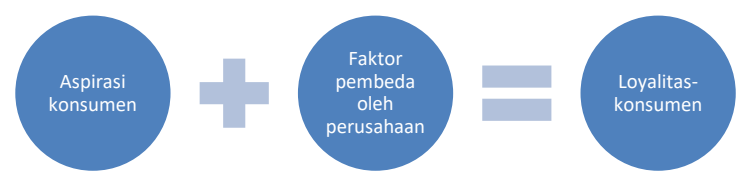

Gambar 12 Aspirasi-faktor pembeda-loyalitas konsumen[8];[9]

Ketiga faktor ini seperti trust-choice-loyalty, harus dapat dibangun secara berkelanjutan oleh lazada untuk dapat memberikan pelayanan yang terbaik kepada konsumen. Jika ketiga hal ini dapat disempurnakan, maka lazada akan mampu membaca perspektif konsumen dengan lebih dalam, dimana lazada akan dapat mengetahui lebih details- apa yang konsumen butuhkaninginkan-dan senang untuk dimiliki, dan dari perspektif merek- produk dan jasa yang ditawarkan memenuhi konsumen di semua tingkatan. Tentu saja, merespons kebutuhan konsumen adalah tentang pilihan, memutuskan motivasi mana yang akan dipenihi dan bagaimana mereka akan mengkombinasikannya untuk menciptakan inovasi baru dari sumber dari keunggulan penawaran kita[10].

\section{KESIMPULAN}

1. Lazada merupakan situs e-commerce terbaik yang pernah ada dan terbesar, dimana lazada menawarkan produk-produknya dengan sangat menarik, di sisi lain, lazada memiliki hard skills dan soft skills yang memadai sehingga lazada mampu bersaing secara global dengan situs e-commerce lainnya.

2. Lazada harus dapat mengembangkan tiga hal penting yang dapat menjadi dasar kekuatan besar dalam mengembangkan situs business online nya. Lazada harus sangat memperhatikan trust-choice-loyalitas yang dimiliki oleh konsumen, sehingga dapat menguasai pasar secara signifikan.

3. Perhatikan budaya dan servis atau jasa di setiap Negara secara lebih teliti dan details, hal ini akan dapat sangat membantu lazada dalam meningkatkan keuntungan bagi perusahaan.

\section{SARAN}

Lazada dapat mempertimbangkan kedua pembanding di bawah ini, sebagai profil kekuatan konsumen, dimana terdapat dua sisi yang bertolak belakang, dan lazada harus dapat mengkombinasikan kedua hal tersebut untuk dapat memperoleh keuntungan yang maksimum.

Tabel 1 Merek dan inovasi

\begin{tabular}{|c|c|}
\hline Merek mendefinisikan perusahaan atau produk & Merek merefleksikan aspirasi konsumen \\
Komunikasi dengan kampanye massal & Komunikasi melalui dialog interaktif \\
Standar produk dan terpisah & Penawaran yang melibatkan setiap segmen \\
\hline $\begin{array}{c}\text { Didistribusikan melalui jalur-jalur yang telah ditentukan } \\
\text { Harga didasarkan pada competitor dan biaya } \\
\text { Hubungan dicari oleh penyuplai }\end{array}$ & Bermitra dengan yang lain untuk menciptakan solusi \\
Inovasi mendorong derivasi produk & Harga didasarkan oleh nilai yang dianggap pantas \\
Strategi didasarkan pada kapabilitas saat ini & Memfasilitasi hubungan antar konsumen \\
Diukur berdasarkan metric keuangan & Inovasi menentukan ulang konteks pasar \\
Secara keseluruhan, perusahaan melakukan bisnis dengan \\
caranya sendiri (yang dianggap baik)
\end{tabular}$\quad$\begin{tabular}{c} 
Strategi didasarkan pda kesempatan terbaik \\
\hline
\end{tabular}

Dari kedua pembanding di atas, maka dihasilkan pertanyaan-pertanyaan penting yang dapat lazada pikirkan untuk strategi berikutnya dalam meraih pasar dan meningkatkan keuntungan, antara lain: (1) Apakah merek anda menentukan target konsumen anda dan ambisi mereka, atau dengan arogan membicarakan bisnis atau produk anda dan apa yang bisa dilakukannya. (2) Apakah riset anda masih terpusat pada statistic rata-rata atau prasangka? Atau riset anda 
mendengarkan dan menggali lebih dalam lagi kebutuhan dan keinginan yang sesunguhnya dari setiap individu?. (3) Apakah anda masih menjadikan konsumen subjek dari kampanye komunikasi terselubung atau mencoba menjual apa yang anda inginkan, kapan dan bagaimana anda tentukan, bukan apa yang mereka inginkan berdasarkan syarat dari mereka?. (4) Apakah jalur distribusi anda dipilih karena kenyamanan efesiensi anda, daripada siapa dan dimana konsumen anda inginkan?. (5) Apakah model penentuan harga anda bermain di margin competitor langsung anda, daripada didasarkan pada nilai relative yang diterima oleh sudut pandang konsumen anda terhadap pilihan alternative?. (6) Apakah anda masih berusaha untuk mempengaruhi konsumen anda untuk memiliki hubungan dengan perusahaan anda, ketika mereka akan lebih jauh berterima kasih untuk menghubungkan mereka dengan orang-orang seperti mereka?. (7) Apakah anda cukup berani untuk memimpin pasar, mengambil resiko dan menentukan aturan-aturan baru, untuk membentuk nasib anda sendiri atau anda senang hidup dengan penentuan dari orang lain? Buatlah profil perusahaan lebih terfokus dan lebih melihat konsumen lebih dalam lagi, meskipun ini sangat penting untuk menjaga keseimbangan, tetapi keseimbangan terkadang, harus dimulai dari luar ke dalam.

\section{DAFTAR PUSTAKA}

[1] J. Peppard, R. D. Galliers, and A. Thorogood, "Journal of Strategic Information Systems Information systems strategy as practice: Micro strategy and strategizing for IS," $J$. Strateg. Inf. Syst., pp. 1-10, 2014.

[2] A. calberto, J \& abaresi, "LAZADA'S LAST MILE: WHERE NO E-COMMERCE COMPANY IN VIETNAM HAD GONE BEFORE," pp. 117-126, 2017.

[3] D. P. Carter, C. M. Weible, S. N. Siddiki, and X. Basurto, "Integrating core concepts from the institutional analysis and development framework for the systematic analysis of policy designs: An illustration from the US National Organic Program regulation," $J$. Theor. Polit., vol. 28, no. 1, pp. 159-185, 2016.

[4] K. Ilieska, "Customer Satisfaction Index - as a Base for Strategic Marketing Management," vol. 2, no. 4, pp. 327-331, 2013.

[5] F. C. Lunenburg, "Organizational Structure : Mintzberg' s Framework," Int. J. Sch., vol. 14, no. 1, pp. 1-8, 2012.

[6] I. Gamayanto, "Porter S Five Forces Model Scott Morton S Five Forces Model Bakos Treacy Model Analyzes Strategic Information Systems Management," J. Inform., vol. 5, no. 2, p. pp.127-134, 2004.

[7] McKinsey Quarterly (2008), Enduring Ideas: The 7-S Framework, McKinsey \& Company

[8] Fisk,P (2006), Marketing Genius, Capstone

[9] Fisk,P (2008), Business Genius: A More Inspired Approach to Business Growth, Capstone; 1 edition

[10] Kartajaya (2005), MarkPlus On Strategy, PT.Gramedia Pustaka 